\title{
Cytokine measurements in Brazilian postmenopausal osteoporosis patients reveal high levels of IL-8
}

\author{
Dosagem de citocinas em pacientes brasileiras com osteoporose pós-menopausa \\ revela altos níveis de $I L-8$
}

\author{
Pablo Ramon Gualberto Cardoso', Thiago Sotero Fragoso ${ }^{2}$, Alexandre Domingues Barbosa², \\ Moacyr Jesus Barreto de Melo Rêgo', Ivan da Rocha Pitta' ${ }^{1}$, Angela Luzia Branco Pinto Duarte ${ }^{2}$, \\ Claudia Diniz Lopes Marques ${ }^{2}$, Maira Galdino da Rocha Pitta $₫$ \\ 1 Laboratório de Imunomodulação e Novas Abordagens Terapêuticas (LINAT), Núcleo de Pesquisa em Inovação Terapêutica Suely Galdino (NUPIT-SG),
Universidade Federal de Pernambuco (UFPE). Recife, PE, Brazil. \\ ${ }^{2}$ Serviço de Reumatologia, Hospital das Clínicas de Pernambuco, Universidade Federal de Pernambuco (UFPE). Recife, PE, Brazil.
}

\section{ABSTRACT}

Aims: Osteoporosis is a common disease that affects mostly women and has been associated with the immune system. The aims of this study were to evaluate the serum levels of inflammatory cytokines in women with postmenopausal osteoporosis and to investigate their relationship with clinical and laboratory parameters.

Methods: This study recruited patients with postmenopausal osteoporosis (osteoporosis group) and non-osteoporotic postmenopausal women (control group) matched for age. All patients and controls had their bone mineral density measured for the diagnosis of osteoporosis and answered a clinical questionnaire. Blood samples were collected for cytokine measurements. Cytokines IFN- $\gamma$, IL-1 $\beta$, IL-6, IL-8, IL-9, IL-10, IL-17A, IL-22, IL-27, IL-29, IL-35, and TNF- $\alpha$ were measured by an enzyme-linked immunosorbent assay.

Results: Twenty-nine out of the $52(55.8 \%)$ postmenopausal osteoporosis patients showed high levels of IL-8, while no patients from the control group $(n=21)$ showed IL-8 values above the detection limit $(\mathrm{p}<0.0001)$. Higher levels of IFN- $\gamma$ and IL-35 were associated with the control group, with $p$ values of 0.0053 and 0.0214 , respectively. In the osteoporosis group, IFN- $\gamma$ was correlated with longer duration of smoking ( $\mathrm{p}=0.003$ ), IFN- $\gamma$ and IL- 6 were correlated with higher age at menarche $(\mathrm{p}=0.0454$ and $\mathrm{p}=0.0380)$, IL-22 was correlated with duration of menopause $(\mathrm{p}=0.0289)$ and IL-9 with calcium intake $(\mathrm{p}=0.019)$. The other cytokines showed no association or correlation with clinical parameters.

Conclusions: IL-8 was elevated in the serum of patients with postmenopausal osteoporosis, perhaps because it may trigger osteoclast activation and bone wear in osteoporosis. Higher levels of IFN- $\gamma$, IL-6, IL-9, IL-22, IL-27, and IL-35 were also associated with the osteoporosis group patients and showed significant correlation with clinical parameters in postmenopausal osteoporosis.

KEY WORDS: interleukins; age-related osteoporosis; osteoporosis, postmenopausal; vitamin D; bone density.

\section{RESUMO}

Objetivos: A osteoporose é uma doença comum, que afeta principalmente as mulheres e tem sido associada com o sistema imune. Este estudo objetivou avaliar níveis séricos de citocinas inflamatórias em mulheres pós-menopáusicas com osteoporose, assim como investigar as suas relações com parâmetros clínicos e laboratoriais.

Métodos: Este estudo recrutou pacientes com osteoporose pós-menopausa e voluntárias sem a doença, pareadas por idade. Todas as pacientes do grupo com osteoporose e as integrantes do grupo controle passaram pelo exame de mensuração de densidade óssea para diagnosticar a doença e todas responderam a um questionário clínico. Amostras de sangue foram coletadas para as dosagens séricas. As citocinas IFN- $\gamma$, IL-1 $\beta$, IL-6, IL-8, IL-9, IL-10, IL-17A, IL-22, IL-27, IL-29, IL-35 e TNF- $\alpha$ foram dosadas por ensaio imunoenzimático.

Resultados: Vinte e nove entre as $52(55,8 \%)$ pacientes com osteoporose pós-menopausa mostraram altos níveis de IL-8, enquanto nenhuma integrante do grupo controle teve valores de IL- 8 acima do nível de detecção do kit $(p<0,0001)$. Altos níveis de IFN- $\gamma$ and IL-35 foram associados ao grupo controle, com valores de $p$ de 0,0053 and 0,0214 respectivamente. No grupo osteoporose, IFN- $\gamma$ mostrou correlação com o tempo de duração do tabagismo ( $\mathrm{p}=0,003)$. IFN- $\gamma$ e IL-6 foram correlacionadas com a idade de ocorrência da menarca $(\mathrm{p}=0,0454 \mathrm{e} \mathrm{p}=0,0380)$. A citocina IL-22 correlacionou-se com a duração da menopausa ( $p=0,0289)$, e a IL-9 com a ingestão de mais cálcio na dieta ( $p=0,019)$. As outras citocinas dosadas não mostraram associações ou correlações com os parâmetros clínicos.

Conclusões: A IL-8 mostrou-se elevada no soro das pacientes com osteoporose pós-menopausa, talvez por atuar como um gatilho para a ativação dos osteoclastos e desgaste ósseo que ocorre na osteoporose. Níveis mais altos de IFN- $\gamma$, IL-6, IL-9, IL-22, IL-27 e IL-35 também estiveram presentes no soro das pacientes do grupo osteoporose e mostraram associações significativas com os parâmetros clínicos na osteoporose pós-menopausa.

DESCRITORES: interleucinas; osteoporose relacionada à idade; osteoporose pós-menopausa; vitamina D; densidade óssea. 
Abbreviations: CG, control group; OG, osteoporosis group; IL, interleukin; OPG, osteoprotegerin; RANK, receptor activator of nuclear factor $\kappa \mathrm{B}$; RANKL, receptor activator of nuclear factor $\kappa$ B ligand; TNF, tumor necrosis factor; IFN, interferon; DEXA, dual-energy x-ray absorptiometry.

\section{INTRODUCTION}

Osteoporosis is a skeletal condition that affects millions of people around the world. It is characterized by low bone mass, which is associated with reduced bone strength and with an increased risk of fractures [1]. Osteoporosis remains an underdiagnosed disease in many countries, and about nine million people worldwide are diagnosed with it each year after suffering osteoporotic fractures [2]. Fractures can result in poor quality of life, long hospital stays, and higher mortality, thus being costly both to the patient and to the healthcare system [3].

Recent studies have linked osteoporosis to the immune system, and osteoimmunology is now recognized as a new area of study. Studies show that bone wear can be worsened by the activation of $\mathrm{T}$ cells at the site of excavation [4]. This action can be consolidated with the role of receptor activator of nuclear factor kappa B (RANK) and interferongamma (IFN- $\gamma)$ in the increase of bone destruction and/or activation of other cells, such as fibroblasts, that secrete RANK [5]. However, osteoclasts, influenced by pro-inflammatory cytokines and anti-osteoclastogenic cytokines, can suppress such activity. This regulation is important in pathological control of the immune system once the production of pro-inflammatory cytokines is exacerbated [6]. In addition, transcription factors, signaling molecules, and receptors are involved in this microenvironment [7].

Epidemiological studies have identified a higher incidence of osteoporosis in some inflammatory conditions, and cytokines and molecular mediators, such as receptor activator of nuclear factor kappa B ligand (RANKL), osteoprotegerin (OPG), interleukin (IL)-1, IL-6, tumor necrosis factor (TNF)- $\alpha$, interferon (IFN) $-\gamma$ and macrophage colony-stimulating factor (M-CSF), have been implicated in bone remodeling and, consequently, in the pathogenesis of osteoporosis [8]. They have been described as the main factors involved in bone wear [8].

Studies on involvement of osteoporosis with the immune system could shed further light upon this condition. The present study aimed to evaluate the serum levels of IFN- $\gamma$, IL-1 $\beta$, IL-6, IL-8, IL-9, IL-10,
IL-17A, IL-22, IL-27, IL-29, IL-35, and TNF- $\alpha$ in postmenopausal Brazilian women diagnosed with osteoporosis and to investigate their relationships with clinical and laboratory parameters.

\section{METHODS}

\section{Study population}

Postmenopausal volunteers were recruited by convenience sampling from the Rheumatology Division of the Clinical Hospital of the Federal University of Pernambuco (Recife, Brazil). The osteoporosis group (OG) included patients whose diagnosis was confirmed by dual-energy X-ray absorptiometry (DEXA). The control group (CG), however, included postmenopausal volunteers in the same age range, but not diagnosed with osteoporosis.

The following exclusion criteria were used: hysterectomy; presence of immune-mediated disease; immunodeficiency; use of immunosuppressive drugs; bone metabolic diseases; and cancer. Those patients with bone mineral density below 18 were also excluded as very low densities are usually due to other pathological processes.

All subjects signed a consent form, which clarified the participation in this study. The study protocol (no. 31631/12) was approved by the Research Ethics Committee of the Federal University of Pernambuco.

\section{Diagnosis of osteoporosis}

Radiographs of the spine and hip detected any fracture risk. Bone mineral density measured by DEXA was used to diagnose osteoporosis, following the World Health Organization criteria [9]. Patients were assigned to the OG or CG based on DEXA results. Lumbar spine, proximal femur, and distal radius were examined.

\section{Study sample}

After clinical evaluation, blood samples were collected $(6 \mathrm{~mL})$ and centrifuged, and the serum was stored at $-80^{\circ} \mathrm{C}$ until it could be tested. The clinical parameters of postmenopausal patients with osteoporosis are summarized in Table $\mathbf{1 .}$

\section{Cytokine measurement}

Serum cytokines were analyzed using an enzymelinked immunosorbent assay (ELISA) sandwich kit (Ebioscience, San Diego, CA, USA, and BD 
Table 1. Demographic, clinical, and laboratory parameters of 52 women with postmenopausal osteoporosis included in the osteoporosis group.

\begin{tabular}{|c|c|}
\hline Clinical Parameters & Mean (minimum and maximum) \\
\hline Age at menarche, years & $14(9-18)$ \\
\hline Years since menopause, years & $13(3-31)$ \\
\hline Body mass index & $26.5(18-34.4)$ \\
\hline Obesity (n) & 12 \\
\hline Smoking (n) & 19 \\
\hline Smoking duration, years & $8.28(0.1-45)$ \\
\hline $\begin{array}{l}\text { Bone mineral density, } \mathrm{g} / \mathrm{cm}^{2} \\
\text { Femoral neck } \\
\text { Lumbar spine }\end{array}$ & $\begin{array}{l}0.765(0.596-0.989) \\
0.796(0.553-0.953)\end{array}$ \\
\hline $\begin{array}{l}\text { Site of osteoporosis } \\
\text { Femoral neck }(n) \\
\text { Lumbar spine }(n)\end{array}$ & $\begin{array}{c}6 \\
48\end{array}$ \\
\hline Osteoporotic fractures & 1 \\
\hline $\begin{array}{l}\text { Treatment } \\
\text { Vitamin D supplementation (n) } \\
\text { Calcium supplementation (n) } \\
\text { Bisphosphonates (n) }\end{array}$ & $\begin{array}{l}27 \\
30 \\
31\end{array}$ \\
\hline Laboratory parameters & Median (minimum and maximum) \\
\hline Vitamin D (ng/mL) & $28.1(13.1-49.9)$ \\
\hline Calcium (mg/dL) & $9.7(7.5-11.7)$ \\
\hline Parathormone $(\mathrm{pg} / \mathrm{mL})$ & $58.6(17.9-126.0)$ \\
\hline $\begin{array}{l}\text { Treatment } \\
\text { Vitamin D supplementation n (\%) } \\
\text { Calcium supplementation } \mathrm{n}(\%) \\
\text { Bisphosphonates } \mathrm{n}(\%)\end{array}$ & $\begin{array}{l}27(51.9 \%) \\
30(57.6 \%) \\
31(59.6 \%)\end{array}$ \\
\hline
\end{tabular}

Biosciences, San Diego, CA, USA), according to the manufacturer's instructions. First, ELISA plates were sensitized with a capture antibody and blocked with $2 \%$ bovine serum albumin. The samples were placed in the ELISA's plate after the standard curve. Afterwards, the detection antibody was added (jointly or not with peroxidase, depending on the manufacturer's kit). The substrate solution was added and the stop solution blocked the reaction in the end. ELISA plates were read at $450 \mathrm{~nm}$ and $570 \mathrm{~nm}$ (EL808, Biotek, Winooski, VT, USA). The lower limit of detection for the ELISA was $62.5 \mathrm{pg} / \mathrm{mL}$ for IL-27; $15.62 \mathrm{pg} / \mathrm{mL}$ for IL-22 and TNF- $\alpha ; 7.81 \mathrm{pg} / \mathrm{mL}$ for IL-29; $4.68 \mathrm{pg} / \mathrm{mL}$ for IL-6, IL-10, and IFN- $\gamma ; 3.9 \mathrm{pg} / \mathrm{mL}$ for IL- $1 \beta$ and IL-17A; $1.95 \mathrm{pg} / \mathrm{mL}$ for IL-8; $0.78 \mathrm{pg} / \mathrm{mL}$ for IL-9 and IL-35.

\section{Measurement of 25-hydroxyvitamin D3 (vitamin D) serum levels}

Vitamin D levels were determined by chemiluminescent immunoassay (CLIA) (LIAISON,
DiaSorin Inc., Atlanta, GA, USA). Normal vitamin D serum levels were defined as $>30 \mathrm{ng} / \mathrm{mL}$, whereas values equal to $10-30 \mathrm{ng} / \mathrm{mL}$ and $<10 \mathrm{ng} / \mathrm{mL}$ were regarded as insufficient and deficient, respectively. Values above $100 \mathrm{ng} / \mathrm{mL}$ were considered to be toxic [10].

\section{Statistical analysis}

The median, maximum, and minimum were calculated for nonparametric data analysis, and the mean and standard error of the mean were used for normal distribution. The D'Agostino K-squared test was used to assess normal distribution. Cytokine measurements are presented as median, maximum, and minimum. The Mann-Whitney U test was used to compare nonparametric data (ordinal and unpaired) between two groups. The Kruskal-Wallis test was employed for the comparison of three or more groups. The chi-square test was used for nominal variables with three or more unpaired groups. Pearson's correlation coefficient and linear regression were used to assess the association and/or correlation of cytokines and clinical parameters in parametric data. Spearman's rank correlation coefficient was used for nonparametric data, and its strength $\left(\mathrm{R}^{2}\right)$ was as follows: $0<\mathrm{R}^{2} \leq 0.35=$ weak correlation; $0.35<\mathrm{R}^{2} \leq 0.67=$ moderate correlation; $0.67<\mathrm{R}^{2} \leq 1=$ strong correlation. Sensitivity and specificity tests were performed, using DEXA results as gold standard.

All statistical analyses were made using the GraphPad Prism 6.01 software and a significance level of $5 \%$.

\section{RESULTS}

The sample consisted of 73 volunteers, 52 with postmenopausal osteoporosis (OG) and 21 agematched postmenopausal women without osteoporosis (CG). The median age was 59 years (minimum 52, maximum 68 years) in the $\mathrm{OG}$ and 58 years (minimum 50 , maximum 66 years) in the CG.

Thirty-one patients in the OG had low levels of vitamin D. Insufficient levels were found in 17 patients and 14 had vitamin D deficiency. Only five patients had serum calcium levels below the reference values. Parathyroid hormone levels were elevated in six patients, but had no correlation with hypocalcemia. The levels of vitamin $\mathrm{D}$, parathormone, and calcium were classified as normal, insufficient, or overexpressed according to test references (Table 1). 


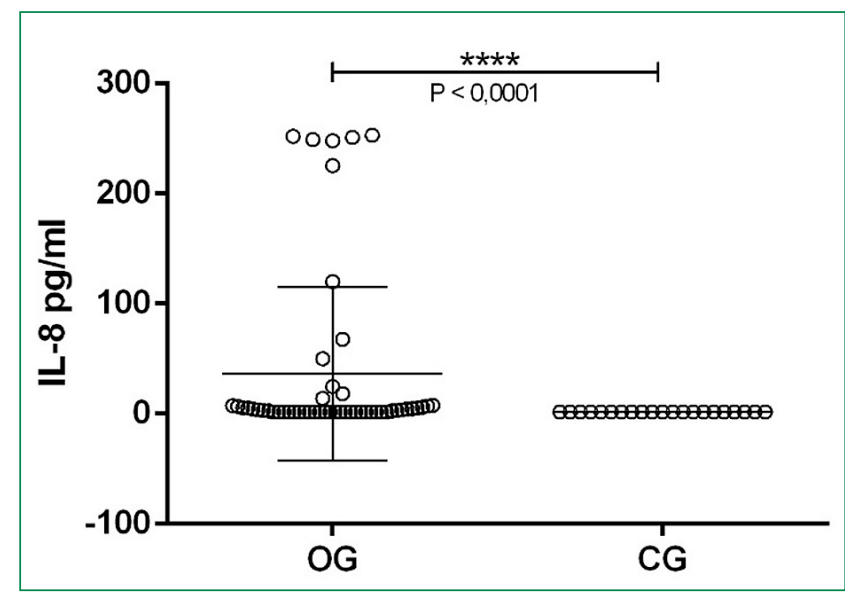

Figure 1. Interleukin (IL)-8 serum levels in the postmenopausal osteoporosis group (OG) and in the control group (CG). IL-8 levels were significantly higher in the OG (Mann-Whitney test).

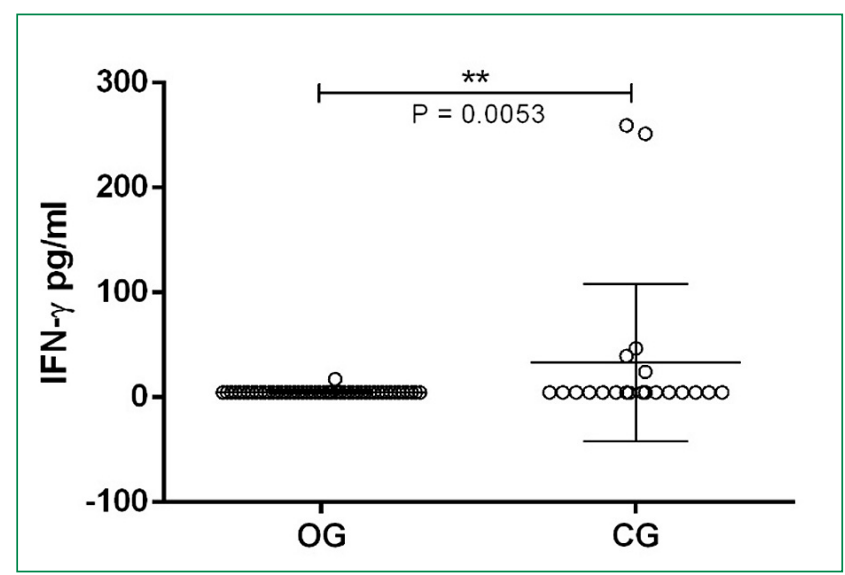

Figure 2. Interferon- $\gamma(\mathrm{IFN}-\gamma)$ serum levels in the postmenopausal osteoporosis group (OG) and in the control group (CG). IFN- $\gamma$ levels were significantly higher in the CG (Mann-Whitney test).

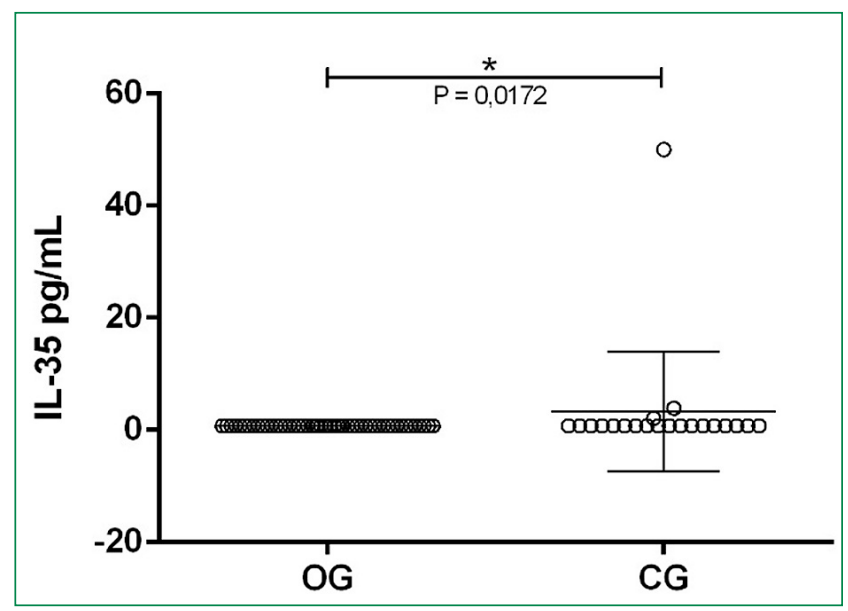

Figure 3. Interleukin (IL)-35 serum levels in the postmenopausal osteoporosis group (OG) and in the control group (CG). IL-35 levels were significantly higher in the CG (Mann-Whitney test).
IL-8 had significantly higher levels in the OG, a specificity of $100 \%$, and a sensitivity of $56 \%$ for the presence of osteoporosis. Twenty-nine out of $52(55.8 \%)$ postmenopausal osteoporosis patients showed positive levels of IL-8. No patients from the CG showed IL- 8 values above the detection limit $(\mathrm{p}<0.0001)$ (Figure 1).

Higher levels of IFN- $\gamma$ and IL-35 were associated with the CG, with p values of 0.0053 and 0.0214 , respectively (Figures 2 and 3). IL-1 $\beta$, IL-6, IL-9, IL-10, IL-17A, IL-22, IL-27, IL-29, and TNF- $\alpha$ were not associated with osteoporosis.

In addition, the relationships between the values obtained from serum cytokine and clinical parameters present in the OG were analyzed. IFN- $\gamma$ and IL- 6 were higher in patients with delayed menarche. IFN- $\gamma$ was also correlated with smoking duration. Patients with longer smoking history had higher levels of IFN- $\gamma$. IL-27 was lower in patients with early menarche. Levels of IL-22 were inversely correlated with the duration of menopause (higher in patients who had a brief menopause). Daily calcium intake was correlated with IL-9. IL-1 $\beta$, IL-10, IL-17A, IL-29, and TNF- $\alpha$ were not associated or correlated with the analyzed parameters (Table 2).

\section{DISCUSSION}

This study aimed to detect circulating cytokine levels in the serum of postmenopausal osteoporosis patients. High levels of IL-8 were found in postmenopausal osteoporosis patients. This is new and important information since, to our knowledge, no studies have shown an association of this cytokine with postmenopausal osteoporosis.

IL-8 has been described as being responsible for neutrophil chemotaxis and degranulation [14]. IL-8 has also already been reported in many diseases such as cancer and rheumatoid arthritis [15]. Yet, there are no studies on the association of IL- 8 with bone wear in osteoporosis.

There is still no serum biomarker for postmenopausal osteoporosis that could identify it or even prevent it. The diagnosis is made primarily by bone density measurements or by the presence of bone fracture [12]. About 20 years ago, the association of the T-score obtained by bone density represented a landmark in the diagnosis of osteoporotic damage. Therefore, in the past, if there was any risk of fractures because of bone fragility, bisphosphonate therapy was initiated immediately in premenopausal or postmenopausal osteoporosis patients [13]. 
Table 2. Relationships (correlations or associations) between serum cytokine levels and clinical and laboratory parameters in 52 patients with postmenopausal osteoporosis (osteoporosis group).

\begin{tabular}{|c|c|c|c|c|c|c|c|c|c|c|c|c|c|c|}
\hline \multirow{3}{*}{ Cytokine } & \multicolumn{14}{|c|}{ Clinical Parameters - $\mathbf{p}$ values } \\
\hline & \multirow[b]{2}{*}{ Age } & \multirow{2}{*}{$\begin{array}{c}\text { Age at } \\
\text { menarche }\end{array}$} & \multirow{2}{*}{$\begin{array}{c}\text { Peri- } \\
\text { menopause }\end{array}$} & \multirow{2}{*}{$\begin{array}{l}\text { Duration of } \\
\text { menopause }\end{array}$} & \multirow{2}{*}{$\begin{array}{c}\text { Cigarettes/ } \\
\text { day }\end{array}$} & \multirow{2}{*}{$\begin{array}{l}\text { Smoking } \\
\text { duration }\end{array}$} & \multirow{2}{*}{$\begin{array}{l}\text { Physical } \\
\text { activity }\end{array}$} & \multirow{2}{*}{$\begin{array}{c}\text { Calcium } \\
\text { supplement }\end{array}$} & \multirow[b]{2}{*}{ BMI } & \multicolumn{2}{|c|}{ DEXA by site } & \multirow{2}{*}{$\begin{array}{l}\text { Serum } \\
\text { calcium }\end{array}$} & \multirow[b]{2}{*}{ PTH } & \multirow{2}{*}{$\begin{array}{l}\text { Vitamin } \\
\text { D }\end{array}$} \\
\hline & & & & & & & & & & $\begin{array}{l}\text { Lumbar } \\
\text { spine }\end{array}$ & Femur & & & \\
\hline Statistical Test & PC & PC & PC & SC & PC & PC & PC & PC & PC & MT & KT & PC & PC & PC \\
\hline IFN- $\gamma$ & 0.750 & $0.045^{*}$ & 0.161 & 0.171 & 0.718 & $0.003^{*}$ & 0.555 & 0.984 & 0.155 & 0.960 & 0.960 & 0.679 & 0.326 & 0.883 \\
\hline IL-1 $\beta$ & 0.494 & 0.336 & 0.419 & 0.828 & 0.283 & 0.492 & 0.950 & 0.260 & 0.623 & 0.999 & 0.613 & 0.694 & 0.979 & 0.915 \\
\hline IL-6 & 0.602 & $0.038^{*}$ & 0.858 & 0.860 & 0.576 & 0.970 & 0.541 & 0.278 & 0.832 & 0.063 & 0.626 & 0.131 & 0.730 & 0.882 \\
\hline IL-8 & 0.812 & 0.683 & 0.050 & 0.175 & 0.470 & 0.523 & 0.488 & 0.264 & 0.728 & 0.222 & 0.520 & 0.274 & 0.727 & 0.680 \\
\hline IL-9 & 0.391 & 0.324 & 0.298 & 0.171 & 0.865 & 0.234 & 0.555 & $0.019 *$ & 0.291 & 0.999 & 0.629 & 0.976 & 0.513 & 0.356 \\
\hline IL-10 & 0.632 & 0.744 & 0.657 & 0.796 & 0.572 & 0.117 & 0.181 & 0.356 & 0.351 & 0.675 & 0.330 & 0.882 & 0.311 & 0.366 \\
\hline IL-22 & 0.240 & 0.453 & 0.268 & $0.028+$ & 0.621 & 0.354 & 0.278 & 0.895 & 0.316 & 0.220 & 0.813 & 0.803 & 0.592 & 0.954 \\
\hline IL-27 & 0.779 & $0.006^{\dagger}$ & 0.983 & 0.859 & 0.444 & 0.742 & 0.167 & 0.325 & 0.875 & 0.562 & 0.140 & 0.753 & 0.722 & 0.651 \\
\hline IL-29 & 0.822 & 0.857 & 0.777 & 0.765 & 0.719 & 0.176 & 0.446 & 0.179 & 0.246 & 0.671 & 0.902 & 0.810 & 0.668 & 0.502 \\
\hline TNF- $\alpha$ & 0.879 & 0.366 & 0.627 & 0.812 & 0.387 & 0.614 & 0.641 & 0.908 & 0.485 & 0.367 & 0.460 & 0.730 & 0.527 & 0.148 \\
\hline
\end{tabular}

BMI, body mass index; PTH, parathormone; IL, interleukin; IFN, interferon; TNF, tumor necrosis factor.

Statistical tests: PC, Pearson's correlation; SC, Spearman's correlation; MT, Mann-Whitney test, KT: Kruskal-Wallis test.

* Positive correlation; + Negative correlation.

IL-17A and IL-35 had no correlation or association with clinical parameters.

There are many current studies linking osteoporosis to vitamin D and estrogen. Nevertheless, few studies have been conducted to elucidate the relationships of the immune system with the clinical parameters of osteoporosis [4]. Some factors encourage the uncoupling of osteoblastic and osteoclastic activities, such as RANK/RANKL/OPG, but little is known about inflammatory factors involved in this process. In inflammatory rheumatic diseases, the situation is worsened by the production of inflammatory cytokines such as TNF- $\alpha$, IL-17A, IL-6 and, more recently, IL-22 [11]. The present study aimed to investigate serum levels of cytokines and to correlate them with clinical and laboratory parameters of postmenopausal osteoporosis.

Delayed menarche is a risk factor for the development of osteoporosis. Some studies indicate that the onset of menarche after the age of 13 years is an aggravating factor for osteoporosis [17]. Our study shows that 23 patients had their menarche before or up to 13 years. On the other hand, 29 patients had their menarche after 14 years of age. This factor may be the major reason for the elevated cytokine levels. Patients with delayed menarche showed high levels of IFN- $\gamma$ and IL- 6 and low levels of IL-27.

IL-27 belongs to the IL-12 family [18] and is associated with osteosarcoma. By contrast, a recent study found that IL-27 could be beneficial by inhibiting osteoclastogenesis [19]. This study corroborates the findings of other ones that consider IL-27 to be an anti-inflammatory factor [20] and a possible positive inflammatory regulator in arthritis [21], multiple sclerosis [22], and even cancer [23]. IL-27 is a cytokine that probably acts in the regulation of bone homeostasis. This cytokine is responsible for decreasing bone degradation by suppressing the expression of RANK precursors (e.g., NFATc1) [24]. Therefore, it is possible to suggest that IL-27 makes an important contribution, with a positive balance regarding cytokine-mediated inflammatory diseases (e.g., osteoporosis). Thus, further research is needed to clarify the role of this cytokine.

The results of this study revealed some interesting correlations and associations between serum levels of cytokines and the clinical criteria for postmenopausal osteoporosis. There were correlation of IFN- $\gamma$ and IL-6 with delayed menarche and of IL-27 with early menarche.

The results have also shown an inverse correlation of IL-22 with the duration of menopause. IL-22 was higher in patients with a brief duration of menopause. Academic data on similar correlations were not found. IL-22 serum levels have been correlated with rheumatoid arthritis [25], squamous cell lesions [26], and systemic lupus erythematosus [27]. IL-22 is a pleiotropic cytokine of the IL-10 family and therefore acts as an anti-inflammatory or pro-inflammatory cytokine [28]. It has been reported that the greater the duration of menopause, the more estrogen is produced, with a gradual, but not abrupt, decline [29]. The production of IL-22 could be an escape from the gradual decay of this hormone. Thus, IL-22 
can regulate the bone system in the presence of low estrogen levels in menopausal women. There was no other association or correlation of IL-22 with postmenopausal osteoporosis.

In conclusion, patients with postmenopausal osteoporosis had significantly high levels of IL-8 when compared to the CG, among whom none had IL-8 levels above the detection limit. Higher levels of IFN- $\gamma$ and IL-35 were associated with the CG. In the OG, IFN- $\gamma$ and IL- 6 were correlated with delayed menarche and IL-27 was higher in patients who had an early menarche. IL-22 was higher in patients who had a brief menopause. Further studies are needed to elucidate how important these circulating cytokines are, particularly IL-8, and to clarify their relationship with postmenopausal osteoporosis.

\section{NOTES}

\section{Financial support}

Funding source: Instituto Nacional de Ciência e Tecnologia para Inovação Farmacêutica (INCT-IF); Coordenação de Aperfeiçoamento de Pessoal de Nível Superior (CAPES); Fundação de Amparo à Ciência e Tecnologia de Pernambuco (FACEPE); Conselho Nacional de Desenvolvimento Científico e Tecnológico (CNPq).

\section{Conflicts of interest}

The authors declare no potential conflicts of interest with respect to the contents of this study.

\section{REFERENCES}

1. Xiong J, Onal M, Jilka RL, Weinstein RS, Manolagas SC, O’Brien CA. Matrix-embedded cells control osteoclast formation. Nat Med. 2011 Sept 11;17(10):1235-41. http://dx.doi.org/10.1038/nm.2448

2. Melton LJ 3rd, Thamer M, Ray NF, Chan JK, Chesnut CH 3rd, Einhorn TA, Johnston CC, Raisz LG, Silverman SL, Siris ES. Fractures attributable to osteoporosis: report from the National Osteoporosis Foundation. J Bone Miner Res. 1997 Jan;12(1):16-23. http://dx.doi. org/10.1359/jbmr.1997.12.1.16

3. Garriguet D. Bone health: osteoporosis, calcium and vitamin D. Health Rep. 2011 Sept;22(3):7-14.

4. Feng W, Xia W, Ye Q, Wu W. Osteoclastogenesis and osteoimmunology. Front Biosci (Landmark Ed). 2014 Jan 1;19:758-67. http://dx.doi. org $/ 10.2741 / 4242$

5. Takayanagi H. Inflammatory bone destruction and osteoimmunology. J Periodontal Res. 2005 Aug;40(4):287-93. http://dx.doi.org/10.1111/ j.1600-0765.2005.00814.x

6. Zupan J, Komadina R, Marc J. The relationship between osteoclastogenic and anti-osteoclastogenic pro-inflammatory cytokines differs in human osteoporotic and osteoarthritic bone tissues. J Biomed Sci. 2012 Mar 1;19:28. http://dx.doi.org/10.1186/1423-0127-19-28

7. Takayanagi H, Kim S, Koga T, Taniguchi T. Stat1-mediated cytoplasmic attenuation in osteoimmunology. J Cell Biochem. 2005 Feb 1;94(2):232-40. http://dx.doi.org/10.1002/jcb.20316

8. Takayanagi H. Osteoimmunology and the effects of the immune system on bone. Nat Rev Rheumatol. 2009 Dec;5(12):667-76. http:// dx.doi.org/10.1038/nrrheum.2009.217

9. Assessment of fracture risk and its application to screening for postmenopausal osteoporosis. Report of a WHO Study Group. World Health Organ Tech Rep Ser. 1994;843:1-129.

10. Holick MF. Vitamin D status: measurement, interpretation, and clinical application. Ann Epidemiol. 2009 Feb;19(2):73-8. http://dx.doi. org/10.1016/j.annepidem.2007.12.001

11. Rocha Junior LF, Rêgo MJ, Cavalcanti MB, Pereira MC, Pitta MG, Oliveira PS, Gonçalves SM, Duarte AL, Lima Mdo C, Pitta Ida R, Pitta MG. Synthesis of a novel thiazolidinedione and evaluation of its modulatory effect on IFN- $\gamma$, IL-6, IL-17A, and IL-22 production in PBMCs from rheumatoid arthritis patients. Biomed Res Int. 2013;2013:926060. http://dx.doi.org/10.1155/2013/926060

12. Marsh D, Woolf A, Akesson K. Osteoporosis and fragility fractures. Preface. Best Pract Res Clin Rheumatol. 2013 Dec;27(6):709-10. http://dx.doi.org/10.1016/j.berh.2014.03.001

13. Lane NE. Osteoporosis: yesterday, today and tomorrow. Rheumatology (Oxford). $2011 \mathrm{July} ; 50(7): 1181-3$. http://dx.doi.org/10.1093/ rheumatology/ker147

14. Hébert CA, Luscinskas FW, Kiely JM, Luis EA, Darbonne WC, Bennett GL, Liu CC, Obin MS, Gimbrone MA Jr, Baker JB. Endothelial and leukocyte forms of IL-8. Conversion by thrombin and interactions with neutrophils. J Immunol. 1990 Nov 1;145(9):3033-40.

15. Capellino S, Cosentino M, Luini A, Bombelli R, Lowin T, Cutolo M, Marino F, Straub RH. Increased expression of dopamine receptors in synovial fibroblasts from patients with rheumatoid arthritis: inhibitory effects of dopamine on interleukin-8 and interleukin-6. Arthritis Rheumatol. 2014 Oct;66(10):2685-93. http://dx.doi.org/10.1002/art.38746

16. Khosropanah H, Sarvestani EK, Mahmoodi A, Golshah M. Association of IL-8 (-251 a/t) gene polymorphism with clinical parameters and chronic periodontitis. J Dent (Tehran). 2013 May;10(4):312-8. 
17. Parker SE, Troisi R, Wise LA, Palmer JR, Titus-Ernstoff L, Strohsnitter WC, Hatch EE. Menarche, menopause, years of menstruation, and the incidence of osteoporosis: the influence of prenatal exposure to diethylstilbestrol. J Clin Endocrinol Metab. 2014 Feb;99(2):594-601. http://dx.doi.org/10.1210/jc.2013-2954

18. Cordoba-Rodriguez R, Frucht DM. IL-23 and IL-27: new members of the growing family of IL-12-related cytokines with important implications for therapeutics. Expert Opin Biol Ther. 2003 Aug;3(5):715-23. http://dx.doi.org/10.1517/14712598.3.5.715

19. Kamiya S, Nakamura C, Fukawa T, Ono K, Ohwaki T, Yoshimoto T, Wada S. Effects of IL-23 and IL-27 on osteoblasts and osteoclasts: inhibitory effects on osteoclast differentiation. J Bone Miner Metab. 2007;25(5):277-85. http://dx.doi.org/10.1007/s00774-007-0766-8

20. Fitzgerald DC, Rostami A. Therapeutic potential of IL-27 in multiple sclerosis? Expert Opin Biol Ther. 2009 Feb;9(2):149-60. http://dx.doi.org/10.1517/14712590802646936

21. Moon SJ, Park JS, Heo YJ, Kang CM, Kim EK, Lim MA, Ryu JG, Park SJ, Park KS, Sung YC, Park SH, Kim HY, Min JK, Cho ML. In vivo action of IL-27: reciprocal regulation of Th17 and Treg cells in collagen-induced arthritis. Exp Mol Med. 2013 Oct 4;45:e46. http://dx.doi.org/10.1038/emm.2013.89

22. Babaloo Z, Yeganeh RK, Farhoodi M, Baradaran B, Bonyadi M, Aghebati L. Increased IL-17A but decreased IL-27 serum levels in patients with multiple sclerosis. Iran J Immunol. 2013 Mar;10(1):47-54.

23. Murugaiyan G, Saha B. IL-27 in tumor immunity and immunotherapy. Trends Mol Med. 2013 Feb;19(2):108-16. http://dx.doi.org/10.1016/j. molmed.2012.12.002

24. Kalliolias GD, Zhao B, Triantafyllopoulou A, Park-Min KH, Ivashkiv LB. Interleukin-27 inhibits human osteoclastogenesis by abrogating RANKL-mediated induction of nuclear factor of activated T cells $\mathrm{c} 1$ and suppressing proximal RANK signaling. Arthritis Rheum. 2010 Feb;62(2):402-13.

25. Zhao L, Jiang Z, Jiang Y, Ma N, Zhang Y, Feng L, Wang K. IL-22+ CD4+ T cells in patients with rheumatoid arthritis. Int J Rheum Dis. 2013 Oct;16(5):518-26 http://dx.doi.org/10.1111/1756-185X.12099

26. Souza JM, Matias BF, Rodrigues CM, Murta EF, Michelin MA. IL-17 and IL-22 serum cytokine levels in patients with squamous intraepithelial lesion and invasive cervical carcinoma. Eur J Gynaecol Oncol. 2013;34(5):466-8.

27. Lin J, Yue LH, Chen WQ. Decreased plasma IL-22 levels and correlations with IL-22-producing T helper cells in patients with new-onset systemic lupus erythematosus. Scand J Immunol. 2014 Feb;79(2):131-6. http://dx.doi.org/10.1111/sji.12135

28. Commins S, Steinke JW, Borish L. The extended IL-10 superfamily: IL-10, IL-19, IL-20, IL-22, IL-24, IL-26, IL-28, and IL-29. J Allergy Clin Immunol. 2008 May;121(5):1108-11. http://dx.doi.org/10.1016/j.jaci.2008.02.026

29. Sioka C, Fotopoulos A, Georgiou A, Xourgia X, Papadopoulos A, Kalef-Ezra JA. Age at menarche, age at menopause and duration of fertility as risk factors for osteoporosis. Climacteric. 2010 Feb;13(1):63-71. http://dx.doi.org/10.3109/13697130903075337

30. Holick MF, Binkley NC, Bischoff-Ferrari HA, Gordon CM, Hanley DA, Heaney RP, Murad MH, Weaver CM; Endocrine Society. Evaluation, treatment, and prevention of vitamin D deficiency: an Endocrine Society clinical practice guideline. J Clin Endocrinol Metab. 2011 July;96(7):1911-30. http://dx.doi.org/10.1210/jc.2011-0385 C 